\title{
DETERMINATION OF MARRIED DISPENSATION NUMBER: 008/Pdt.P/2018/Tgm AND 0012/Pdt.P/2019/Tgm IN MASLAHAH PERSPECTIVE
}

\author{
Tiswarni $^{1}$, Jayusman ${ }^{2}$, Aimas Soleha Rohilati ${ }^{3}$ \\ ${ }^{1}$ UIN Imam Bonjol, Jl. Sudirman No. 15 Padang, Sumatera Barat \\ ${ }^{2}$ UIN Raden Intan, Jl. Letnan Kolonel H Jl. Endro Suratmin, Sukarame, \\ Kec. Sukarame, Kota Bandar Lampung, Lampung 35131 \\ ${ }^{3}$ KUA Kedaton, Bandar Lampung \\ Jl. Rusa, Sukamenanti, Kec. Kedaton, Kota Bandar Lampung, Lampung 35123 \\ Email: ${ }^{1}$ tiswarni@uinib.ac.id; ${ }^{2}$ jayusman@radenintan.ac.id; ${ }^{3}$ sholeha.pss0571@gmail.com
}

\begin{abstract}
This paper aims to analyze the judges' considerations of the Class I B Tanggamus Religious Court in the case of the determination of the Marriage Dispensation Number 008/Pdt.P/2018/PA. Tgm and 0012/ Pdt.P/2019/PA.Tgm, and the reasons put forward by the petitioners, as well as reviewing them from the maslahahah side. This research method is descriptive qualitative, with the Ushul Fiqh approach. Collecting data through documentation and library research, using sources related to the main research problem, both primary and secondary sources with philosophical, juridical, and logical approaches, and content analysis techniques. As a result, the panel of judges gave its decision based on the fact that their marriage could be carried out immediately because the applicants were consensual and always together, and there was a concern that unwanted things would happen in religion or the law. The reasons for parents to marry off their children at a young age (under 19 years) are due to cultural factors, releasing the burden on parents, and because they are pregnant outside of marriage. From the view of maslahah, this dispensation of marriage does not bring benefit, but rather brings harm. Because the impact after marriage, it turns out that one of them always quarrels in his household so he doesn't live together anymore. And one other even though they still live together, but their lives are very deprived and unworthy.
\end{abstract}

Keywords: Marriage dispensation; maslahah

\begin{abstract}
Abstrak: Tulisan ini bertujuan menganalisis pertimbangan hakim Pengadilan Agama Kelas I B Tanggamus dalam perkara penetapan Dispensasi Nikah Nomor 008/Pdt.P/2018/PA. Tgm dan 0012/Pdt.P/2019/PA.Tgm, dan alasan-alasan yang diajukan para pemohon, sekaligus meninjaunya dari sisi maslahahah. Metode penelitian ini bersifat kualitatif deskriptif, dengan pendekatan Ushul Fiqh. Pengumpulan data melalui dokumentasi dan penelitian kepustakaan (library research), dengan menggunakan sumber-sumber yang terkait masalah pokok penelitian, baik sumber primer maupun sekunder dengan pendekatan filosofis, yuridis, dan logis, dan teknik analisis isi (content analysis). Hasilnya, majelis hakim memberikan penetapannya berdasarkan bahwa pernikahan mereka dapat segera dilaksanakan berhubung karena di antara para pemohon telah suka sama suka dan selalu bersama, serta dikhawatirkan terjadi hal-hal yang tidak diinginkan dalam agama maupun undangundang. Adapun alasan orang tua menikahkan anaknya di usia muda (di bawah 19 tahun) adalah karena faktor budaya, melepaskan beban orang tua, dan karena hamil di luar nikah. Dari tinjauan maslahah, dispensasi nikah ini tidak membawa kemaslahatan, tapi justru membawa kemudaratan. Sebab dampaknya setelah pernikahan, ternyata salah satu di antaranya selalu bertengkar dalam rumah tangganya sehingga tidak tinggal bersama lagi. Dan satu lainnya meski masih tinggal bersama, namun kehidupan mereka sangat kekurangan dan tidak layak.
\end{abstract}

Kata kunci: Dispensasi nikah; maslahah 


\section{Introduction}

It is undeniable that in Indonesia there are still many parents who marry off their children when they are underage ${ }^{1}$. This is triggered by various reasons; for example, the culture of marrying young in certain communities. If a girl does not propose to a certain age, then she is considered unsold and is labelled an old maid. This attribute is a very heavy psychological burden for the girl's family so that parents who have daughters are competing to marry off their children even though they are very young.

Apart from the aforementioned background factors, another important cause of underage marriage is the rampant promiscuity of adolescents which leads to pregnancy outside of wedlock; as a result, parents quickly marry off their children. ${ }^{2}$ In this case, people still see that marriage is an effective solution to cover up the shame that has befallen their children. Even though many fiqh scholars have different opinions between being allowed to marry and not getting pregnant outside of marriage, Imam Ash-Syaibani tolerates being allowed to marry a woman who is pregnant outside of marriage as long as she does not have sexual intercourse before the child is born. ${ }^{3}$

1 Siskawati Thaib, Perkawinan Di bawah Umur (Ditinjau Dari Hukum Islam Dan Undang-Undang Nomor 1 Tahun 1974), Lex Privatum Vol. V/No. 9/Nov/2017, p. 48, Siti Hardiyanti Rukmana, Pertimbangan Non Yuridis Dalam Memutuskan Perkara Dispensasi Nikah (Studi Putusan Pengadilan Agama Tanjung Karang Kelas Ia Kota Bandar Lampung), Tesis Magister, UIN Raden Intan Lampung 2019, http://repository.radenintan.ac.id/id/ eprint/6557

2 Sri Ahyani, Pertimbangan Pengadilan Agama Atas Dispensasi Pernikahan Usia Dini Akibat Kehamilan Di Luar Nikah, Jurnal Wawasan Hukum, Vol. 34, No. 1, Februari 2016, p. 31

${ }^{3}$ Anshary. MK, Kamal Muchtar, Asas- Asas Hukum Islam Tentang Perkawinan, (Jakarta: Bulan Bintang, 2010, p. 63
The reasons for filing a marriage dispensation based on Article 7 Paragraph (2) of the Marriage Law have not or have not been regulated has reduced the concept of dispensation itself, as it is explained that dispensation is a limited state administration decision to set aside prohibitions in special cases. Therefore, the formulation of the permissible reasons is the most basic element to which a dispensation can be given. Thus dispensation is intended to resolve certain cases which may clarify the general statement of the purpose of the law, namely the general good. ${ }^{4}$

In order to realize a marriage that is in accordance with the objectives of marriage, Law Number 1 of 1974 concerning Marriage has determined and established the basics that must be carried out in marriage. One of them is Article 7 paragraph (1) which states that: "Marriage is only permitted if the man has reached the age of 19 (nineteen) years and the woman has reached the age of 16 (sixteen) years", and in the following paragraph states that if there is a deviation in Article 7 paragraph (1), he can ask for dispensation at the court or other appointed official. The amendment to law number 1 of 1974 concerning marriage contained in law 16 of 2019 is in article 7 paragraph (1) which states that: Marriage is only permitted if the man and woman have reached the age of 19 (nineteen) years.

In the al-Qur'an it does not specifically discuss the age of marriage, it only determines

\footnotetext{
4 Widihartati Setiasih, Analisis Putusan Dispensasi Nikah Dibawah Umur Dalam Perspektif Perlindungan Perempuan, Jurnal PPKM III (2017) 235 - 245, Vol 4 No 3 (2017): September, p. 337, https://ojs.unsiq.ac.id/ index.php/ppkm/article/view/428/257 dan lih. Nurul Inayah, Penetapan Dispensasi Nikah Akibat Hamil Di Luar Nikah Di Pengadilan Agama Yogyakarta Tahun 2010-2015 (Analisis Hukum Acara Peradilan Agama), Jurnal Al-Ahwal, Vol. 10, No. 2, Desember 2017 M/1439 H, p. 180
} 
with signs and signs of maturity, so it is left to the realm of fiqh and to the Muslims to determine the age limit which should be in accordance with the conditions and signs that have been determined, and adapted to the place where the law will be promulgated. The Word of Allah in Surah al-Nisa verse 1 requires marriage for a male and female partner. Of course, the order is intended for those who are adults.

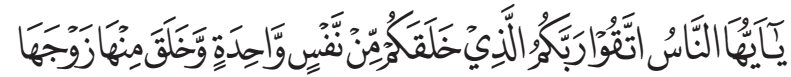

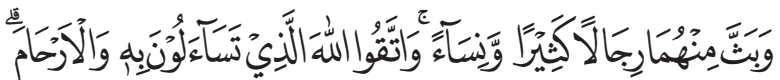

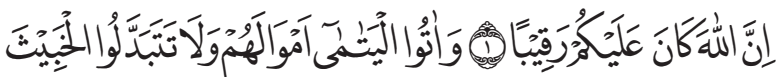

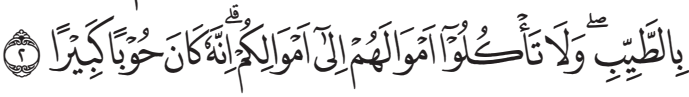
O people, fear your Lord who created you from alone, and from him, Allah created his wife; and from both of them Allah gave birth to a large number of men and women. and fear Allah who by (using) His name you ask one another, and (maintain) good relations. Indeed, Allah is always watching over you. (al-Nisa verse 1)

For a young man, the age for entering the gates of marriage and household life generally focuses on his physical maturity, mental maturity, and his ability to assume responsibility as a husband in his household. That is the standard age for young people unless there are other factors that cause the marriage to take place earlier. For a girl, the age of marriage is because it is related to pregnancy, and it is likely that after marrying there will be a pregnancy. Therefore, it is necessary to take into account the physical and spiritual maturity that makes it possible to carry out the duties as a wife and at the same time as a mother as well as possible, ${ }^{5}$ However, sometimes children who have not reached this stage have already

\footnotetext{
5 Sutan Marajo Nasaruddin Latif, Problematika Seputar Keluarga dan Rumah Tangga, Pustaka Hiddayah, Bandung, 2001, p. 23.
}

married for certain reasons, for this reason, for those who are underage to marry, they must receive a marriage dispensation from the local religious court. ${ }^{6}$

Furthermore, the determination of the dispensation of marriage from 2015 to 2019 at the Religious Court Class IB Tanggamus provides for the determination of 52 cases of marriage dispensation, and 2 of them the determination of the marriage dispensation case determined at the request of the parents (not because they have ever had a husband and wife relationship or are pregnant).

The thing that is interesting for the author in the case that is determined in the average determination is that the prospective bride and groom are already pregnant, while the case that occurred in the Religious Court Class IB Tanggamus in the case of the determination of Marriage Dispensation Number 008/ Pdt.P/2018/PA. Tgm and 0012/Pdt.P/2019/ PA.Tgm, are at the request of parents and without any other shar " $\mathrm{i}$ reason. For this reason, the author wants to examine more deeply the judges' considerations in giving dispensation of marriage and what is the motivation of parents to marry off their children at a young age and then review it with maslahah theory. From the explanation above, some of the issues that need to be examined are how to analyze the judges' considerations on the determination of marriage dispensation number 0008/ Pdt.P/2018/PA.Tgm and 0012/Pdt.P/2019/ PA.Tgm? And 2. How is the review of the issue regarding the judges' considerations in determining the dispensation of marriage Number 0008/Pdt.P/2018/PA.Tgm and 0012/Pdt.P/2019/PA.Tgm?

\footnotetext{
${ }^{6}$ Sri Ahyani, Pertimbangan ..., p. 33-34
} 


\section{Research Method}

This research belongs to the category of normative Islamic law research with the Ushul Fiqh approach. This aims to see how the legal process occurs in reaching a legal opinion in a case. Therefore, this type of research is descriptive qualitative research with a case study model.

To obtain accurate and documentary data, data collection is carried out through documentation and library research, using sources that are related to the main research problem, both primary and secondary sources with a philosophical, juridical, and logical approach $^{7}$, and content analysis techniques. The data analysis was done qualitatively. Data analysis was carried out simultaneously since the data collection process, and finally conclusions were drawn deductively.

\section{Maslahah}

In terms of language, maslahah comes from the word salaha, which literally means the opposite of bad or damaged words. He is mashdar from saluha, which means goodness or regardless of difficulty. ${ }^{8}$ And it can also be said that maslahah is the singular form of masâlih.

As there are two meanings of maslahah, namely maslahah, which means al wrong and maslahah, which means the singular form of al-masâlih. Everything implies the existence of benefits both originally and through processes, such as producing enjoyment and benefits, or prevention and protection such as avoiding obedience. All of that can be called maslahah. ${ }^{9}$ In Arabic the meaning

\footnotetext{
${ }^{7}$ Cik Hasan Bisri, Model Penelitian Figh, (Bogor: Kencana, 2013), Cet. ke-1, Jilid I, h. 377

${ }^{8}$ A. Warson Munawir, Kamus Al Munawir, (Surabaya: Pustaka Progresif, 2016), p. 788-789

9 Rachmat Syafei, Ilmu Ushul Fiqih, (Bandung: Pustaka Setia, 2017), p. 7.
}

of maslahah means actions that encourage human goodness, meaning that everything that is beneficial to humans, either in the sense of attracting or producing, such as producing profit or pleasure or in the sense of rejecting or avoiding such as rejecting fatness or damage. So everything that contains two sides, namely attracting or bringing benefit and rejecting or avoiding fading. ${ }^{10}$

In the study of Islamic legal theory (usûl al-fiqh), maslahah is identified by various designations (attributes), namely principles (al-asl, alqâiidah, al-mabda'), sources or legal arguments (masdar, dalîl), doctrine (al-dâbit), concepts (al-fikrah), methods (al-tarîqah), and theories (al-nazariyyah). Etymologically, the meaning of al-maslahah can mean goodness, usefulness, appropriateness, worthiness, harmony, decency. The word almaslahah is contrasted with the word al-mafsadah which means damage. ${ }^{11}$

Maslahah can be interpreted from two sides, namely in terms of language and in terms of law or syara'. In terms of language, it refers to the purpose of fulfilling human needs and therefore, it contains the meaning of following lust or lust. Whereas in the meaning of syara 'which is the measure and reference is to maintain soul, reason, religion, descent, and property without giving up the goal of fulfilling human needs, namely getting pleasure and avoiding displeasure.

The division of maslahah in terms of strength as evidence or a foundation in determining the law, there are three: (1) maslahah darûriyah (2)

\footnotetext{
10 Amir Syarifudin, Ushul Fiqih,Jilid 2, (Jakarta: Kencana, 2015), p. 366.

${ }^{11}$ Asmawi, "Konseptualisasi Teori Mashlahah", Salam: Jurnal Filsafat dan Budaya Hukum, Vol. 2, No. 1, 2014 , p. 313-314.
} 
maslahah hâjiyah (3) maslahah tahsîniyah, all three have legal powers that are functional, so this classification makes it easier to categorize a problem In terms of the intention of seeking and establishing the law, maslahah is also called munasib. Maslahah in the sense of munasib is divided into three parts: (1) maslahah almu'tabarah (2) maslahah al-mughâh (3) maslahah al-mursalah (islislâh). ${ }^{12}$

Maslahah is used as an effort to istinbat Islamic Law or if you hit a problem it can use the maslahah theory because as a barometer, the scholars limit the freedom of reason in maslahah studies, by setting a number of criteria, as follows:

1. The maslahah is a ratio (ma'qul) and relevant (munasib) to the legal case stipulated.

2. The problem must be accepted by rational thought.

The maslahah must be following the meaning of the Shari'a in stipulating the law, and not contradicting with the arguments, either with the textual arguments or with the basic premises of the substance. In other words, it must be in accordance with the maqâsid syarîah.

Case for Determination of Marriage Dispensation Number 0008/Pdt.P/2018/ PA.Tgm and Number 0012/Pdt.P/2019/PA. Tgm

1. The case for Determination of Marriage Dispensation Number 0008/Pdt.P/2018/ PA.Tgm

a. The case for Determination of Marriage Dispensation

The case for Determination of Marriage Dispensation Number 0008/Pdt.P/2018/ PA.Tgm is:

\footnotetext{
${ }^{12}$ Amir Syarifudin, Ushul Fiqih, p. 372.
}

1) Whereas the petitioner based on his application letter dated January 16, 2018, which is registered at the Registrar's Office of the Tanggamus Religious Court, wants to marry his son named Al-Mukhtarom bin Saparudin who is 18 (eighteen) years old with his future wife Yuli Puji Lestari Binti Sukarmin who is 16 (sixteen)) year.

2) Whereas the conditions for carrying out the marriage both according to the provisions of Islamic law and the prevailing laws and regulations have been fulfilled except for the age requirement for the applicant's child who has not reached the age of 19 (nineteen) years, and because of that the said intention has been rejected by the Office. Religious Affairs (KUA) Kec. Performance with Letter Number B.09.Kua.08.B.2/PW.01/01/2018 dated January 12, 2018.

3) Whereas the marriage is very urgent to take place because both of them have been engaged since approximately one month ago and their relationship has been so close, so that the petitioner is very worried that an act that is prohibited by the provisions of Islamic law will occur if they are not married immediately.

4) Whereas between the Petitioners' children and his future wife, there is no prohibition against marriage.

5) Whereas the petitioner's child has the status of a bachelor, has reached maturity and is ready to become a husband or head of the family.

6) The petitioner is able to pay all costs incurred as a result of this case. ${ }^{13}$

${ }^{13}$ Determination of Marriage Dispensation, Number: 0008/Pdt.P/2018/PA.Tgm, p. 3-4 


\section{b. Legal Considerations}

The judges' legal considerations in this case are:

1) Whereas the aims and objectives of the petitioner's petition areas mentioned above;

2) Whereas the panel of judges has advised and provided sufficient views so that the marriage should be postponed until it is old enough according to the prevailing laws and regulations, however, the petitioner remains with the petition;

3) Whereas the intention of setting the minimum age limit for marriage, as stated in the Elucidation of Article 7 of Law Number 1 of 1974 concerning Marriage, is in the context of consideration of benefit, because marriage requires mental (psychological) and physical maturity. Besides that, it is also necessary to have economic adequacy, the potential for the ability to educate and socialize in social life, all of which are based on the basis of One Godhead;

4) Whereas the conditions of marriage are aimed at the benefit of marriage, including refusing or at least eliminating marital problems such as divorce, inability to educate, economic deficiency, bad offspring, harmony in the household, and so on. Which is based on the interpretation of Surat al-Nisa verse 9 as follows:

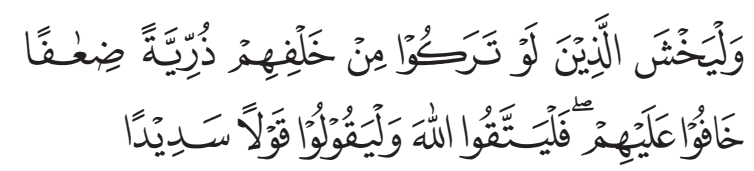

"And fear Allah those who should leave behind them weak children, whom they fear for their welfare. Therefore let them have devotion to Allah, and let them pronounce the true statement."
5) Based on the evidence of letters P1-P5, authentic deeds as referred to in Article 285 R.Bg, are also based on the testimony of witnesses, as well as the statements of the Petitioners 'children and the Petitioners' future wives Kesemuay has provided information which strengthens and proves all the posita of the petitioner's petition, in particular regarding the readiness and maturity of the aspects required to carry out a marriage, as well as clarifying and confirming the reasons and motivation of the petitioner's petition and the petitioner's children;

6) Whereas the Petitioner's child, although not meeting the minimum requirements for marriage age, the panel of judges views that the petitioner's child is capable and mature in various aspects to be responsible in carrying out and fostering mitsaqan ghalidhan, a strong bond, a physical and mental bond in the form of a happy marriage bond. and eternal according to the Supreme Lordship;

7) Whereas the Petitioner, as a biological mother, has stated her ability to guide, foster and assist her child in living his household life, both morally and materially;

8) Whereas the Petitioner's child and his prospective wife do not have any obstacle to marriage, whether it is lineage/descent, sexual relations, sexual relations or religious relations, this is in accordance with Article 8 of Law Number 1 the Year 1974 concerning marriage in conjunction with Article 30-44. Compilation of Islamic Law; ${ }^{14}$

${ }^{14}$ Determination of Marriage Dispensation, Number: 0008/Pdt.P/2018/PA.Tgm, p. 5-6 
Whereas the Majlis considers it necessary to present the appropriate Syariah arguments as follows;

1) The holy book of al-Qur'an surah an-Nur verse 32:

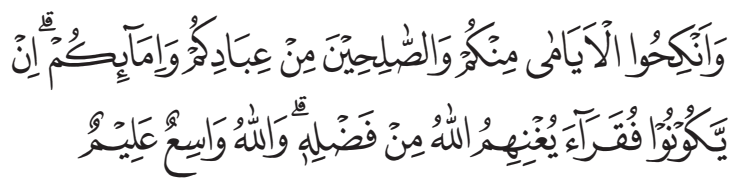
"And marry those who are alone among you, and those who are worthy of marriage from your male and female slave servants, if they are poor, Allah will gather them with His grace and Allah is the most extensive. , lahi is all-knowing."

2) The Safinatun Najah book page 16 which means the following:

"The signs of adulthood (adulthood) are 3 (three) things, namely being 15 years old, for men and women who have dreamed and emitted semen, for men and women aged 19 years and have had menstruation."

\section{c. Legal Establishment}

Based on theaforementioned considerations, the panel of judges subsequently issued a ruling which read as follows:

1) Grants the petitioner;

2) To determine, to give dispensation to the petitioner to marry off the petitioner's child named Al-Mutarom bin Saparudin with his future wife named Yuli Puji Lestari Binti Sukarmin;

3) Charged the court fee to the petitioner, amounting to Rp. 211,000 - (two hundred and eleven thousand rupiahs);
2. Determination of Marriage Dispensation Number 0012/Pdt.P/2019/PA. Tgm.

a. Sitting in the case of the Determination of Marriage Dispensation Number 0012/ Pdt.P/2019/PA. Tgm. are as follows

1) Whereas the petitioner based on his application letter dated January 16, 2018 which was registered at the Registrar's Office of the Tanggamus Religious Court, wants to marry his son Miftahudin bin Solihin who is 18 (eighteen) years 4 (four) months old with his future wife Eliyana Binti Khoiruddin who is 18 (eight) twelve) years and 10 (ten) months.

2) Whereas the conditions for carrying out the marriage both according to the provisions of Islamic law and the prevailing laws and regulations have been fulfilled except for the age requirement for the applicant's child who has not reached the age of 19 (nineteen) years, and because of that the said intention has been rejected by the Office. Religious Affairs (KUA) Kec. Performance with Letter Number B.115/Kua.08.13.2/ PW.01/03/2019 dated March 20, 2019.

3) Whereas the marriage is very urgent to take place because both of them have been engaged since approximately 3 (three) months ago and their relationship has been so close, that the petitioner is very worried that an act that is prohibited by the provisions of Islamic law will occur if they are not married immediately.

4) Whereas between the Petitioners' children and his future wife, there is no prohibition against marriage.

5) Whereas the petitioner's child has the status of a bachelor, and has reached maturity and is ready to become a husband or head of the family. 
6) The petitioner is able to pay all costs incurred as a result of this case. ${ }^{15}$

\section{b. Legal Considerations}

The judges' legal considerations in this case are:

1) Whereas the aims and objectives of the petitioner's petition areas mentioned above;

2) Whereas the panel of judges has advised and provided sufficient views so that the marriage should be postponed until it is old enough according to the prevailing laws and regulations, however, the petitioner remains with the petition;

3) Whereas the intention of setting the minimum age limit for marriage, as stated in the Elucidation of Article 7 of Law Number 1 of 1974 concerning Marriage, is in the context of consideration of benefit, because marriage requires mental (psychological) and physical maturity. Besides that, it is also necessary to have economic adequacy, the potential for the ability to educate and socialize in social life, all of which are based on the basis of One Godhead;

4) Whereas the conditions of marriage are aimed at the benefit of marriage, including refusing or at least eliminating marital problems such as divorce, inability to educate, economic deficiency, bad offspring, harmony in the household, and so on. Which is based on the interpretation of Surat al-Nisa verse 9 as follows:

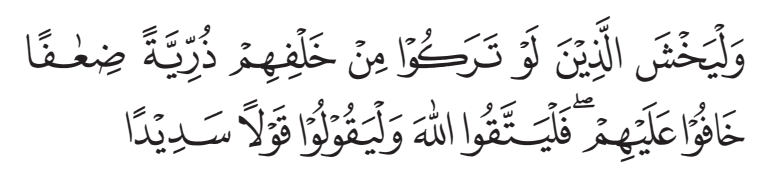

${ }^{15}$ Determination of Marriage Dispensation, Number 0012/Pdt.P/2019/PA.Tgm, p. 1-2
"And fear Allah those who should leave behind them weak children, whom they fear for their welfare. Therefore let them have devotion to Allah, and let them pronounce the true statement."

5) Based on the evidence of letters P1-P5, authentic deeds as referred to in Article 285 R.Bg, are also based on the testimony of witnesses, as well as the statements of the Petitioners 'children and the Petitioners' future wives Kesidangay has provided information that strengthens and proves all the posita of the petitioner's petition, especially regarding the readiness and maturity of the aspects needed to carry out a marriage, besides that it has clarified and confirmed the reasons and motivation for the petitioner's petition and the petitioner's children;

6) Whereas the petitioner's child, although not meeting the minimum requirements for marriage age, the panel of judges views that the petitioner's child is capable and mature in various aspects to be responsible in carrying out and fostering mitsaqan ghalidhan, a strong bond, a physical and mental bond in the form of a happy and eternal according to the One Godhead;

7) Whereas the petitioner, as the biological mother, has stated her ability to guide, foster and assist her child in living his household life, both morally and materially;

8) Whereas the petitioner and his prospective wife's child does not have any obstacle to marriage, whether it is lineage/descent, sexual relations, sexual relations or religious relations, this is following Article 8 of Law Number 1 the Year 1974 concerning marriage in conjunction with Article 3044. Compilation of Islamic Law; 
9) Whereas the Majlis considers it necessary to present the appropriate syar'iyyah argument as follows;

(a) The holy book Al-Qur'an surah An-Nur verse 32:

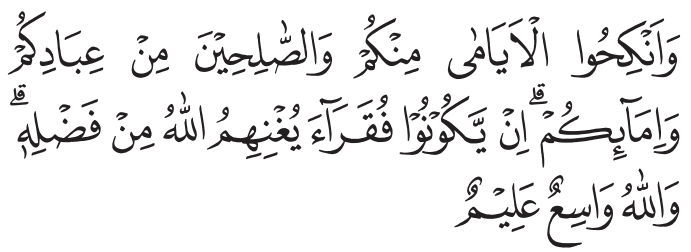

"And marry those who are alone among you, and those who are worthy of the marriage of your male and female slave servants, if they are poor, Allah will gather them with His grace and Allah is the most extensive of gifts. Him, Allah is All-Knowing."

(b) The fiqhiyyah qaidah which reads:

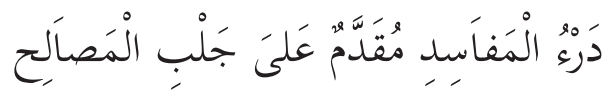

"Rejecting obedience takes precedence over attracting benefit". ${ }^{16}$

\section{c. Legal Establishment}

Basedon theaforementioned considerations, the panel of judges subsequently issued a ruling which read as follows:

1) Grants the petitioner;

2) To determine, to give dispensation to the petitioner to marry off the petitioner's child named Al-Mutarom bin Saparudin with his future wife named Yuli Puji Lestari Binti Sukarmin;

3) Charged the court fee to the petitioner, amounting to Rp. 306,000, - (three hundred and six thousand rupiah); ${ }^{17}$

\footnotetext{
${ }^{16}$ Determination of Marriage Dispensation, Number: 0008/Pdt.P/2018/PA.Tgm, p..3

${ }^{17}$ Determination of Marriage Dispensation, Number: 0008/Pdt.P/2018/PA.Tgm, p.4-5
}

Judges' Considerations in the Determination of Marriage Dispensation Number 0008/ Pdt.P/2018/PA.Tgm and 0012/Pdt.P/2019/ PA.Tgm perspective Maslahah

By examining various cases that have been raised in several writings, especially cases related to marriage issues, the author realizes how important the socialization of Islamic law to society is not only the form of normative legal formulation, but also especially regarding aspects of legal objectives, which are generally not others aim to achieve benefit and avoid oblivion.

The duty of judges as law enforcers, every application of law or legal decisions made by judges should be in line with the objectives of the law to be achieved by syari'at. If the application of formula will conflict with the results of human benefit, the application of the law must be suspended. In order to achieve the benefit, which is the main objective of the application of laws, legal exceptions need to be enforced. The purpose of law enforcement in Islam is a benefit. Maslahah means actions that encourage human goodness, meaning that everything that is beneficial to humans, either in the sense of attracting or producing, such as producing profit or pleasure or in the sense of rejecting or avoiding such as refusing obedience or damage. So everything that contains two sides, namely attracting or bringing benefit and rejecting or avoiding fade. ${ }^{18}$

In the order of the determination of the two Marriage Dispensations above, the Panel of Judges granted the petitioner's petition, namely to grant a Marriage Dispensation to the petitioner to marry off his child. With

\footnotetext{
18 Amir Syarifudin, Ushul Fiqih,Jilid 2, (Jakarta: Kencana, 2015), p. 366
} 
the consideration that there will be a greater madarat if the two candidates for the bride and groom are not married immediately. Mudarat in question arises from the concern of the parents as the petitioner.

The decision of the Panel of Judges did not deviate from the provisions of the Marriage Law which did not specifically discuss Marriage Dispensation and Islamic Law Compilation which implicitly did not prohibit marrying someone whose age was less as stipulated in statutory regulations.

In the study of Islamic legal theory (ushul fiqh), maslahah is identified by various designations (attributes), namely principles (principle, al-asl, al-qẩidah, al-mabda') sources or legal propositions (source, al-masdar), addalîl), doctrine (doctrine, al-dâbit), concepts (concept, al-fikrah), methods (method, altarîqah), and theories (theory, al-nazariyyah) ${ }^{19}$

The foundation of the Islamic Sharia building is represented by maslahah, which is aimed at the interests of human life as a servant of Allah, both concerning his worldly life and his spiritual life. Islamic Sharia upholds the principles of justice ('adâlah), compassion (rahmah), and maslahah. Any rule of law that deviates from these principles is not a part of Islamic Sharia, although rationalization (ta'wîl) is sought to make it a part of Islamic Sharia. The greatness and nobility of Islamic Sharia is manifested in the compatibility of Sharia laws with the development of human life because the maslahah spirit moves it. The existence of maslahah in Islamic Sharia buildings cannot be denied because al-maslahah (المصلحة) and asySyarîsah (الشريعة) have combined and merged, so

${ }^{19}$ Husain Hamid Hisân, Nazariyyat al-Maslahah $f i$ al-Fiqh al-Islâmiy, (Beirut: Dâr al-Nahdah al-'Arabiyyah, 1971), p.607. that the presence of al-maslahah necessitated the demands of al-Syarî̀ah (الشريعة).

Realizing maslahah is a vital thing in Islamic Sharia. In every rule of law, asy-Syâri «transmits maslahah so that goodness/benefit is born and $\mathrm{bad} /$ damage is avoided, which in turn the realization of prosperity and welfare on earth and purity of devotion to Allah. Because, maslahah is actually maintaining and paying attention to the goals of Syara in the form of goodness and benefit desired by Syara, not by human passions. The legal norms contained in the Sharia texts (nusûs asy-syarî̀ah) can certainly manifest maslahah, so that there is no problem outside the guidance of the Sharia text; and because of that, it is not valid to think that maslahah should be prioritized if it contradicts the Sharia text. So, maslahah is essentially the axis of circulation and change of Islamic law, where the interpretation of the Sharia text can rest on it. $^{20}$

Yusuf al-Qaradawi is concerned that the maslahah substance desired by Islamic Sharia to be upheld and maintained is a comprehensive, integral and holistic maslahah, which includes a combination of maslahah dunyawiyyah and maslahah ukhrawiyyah, maslahah maddiyyah and maslahah rûhiyyah, maslahah fardiyyah and maslahah. maslahah qaumiyyah khâssah and maslahah insâniyyah 'âmmah, maslahah hâdirah and maslahah mustaqbalah. On this basis, Yusuf al-Qaradawi emphasized that the concept of maslahah which animates Islamic Sharia cannot be identified with utility and pragmatism, which not a bene originated from materialism. ${ }^{21}$

\footnotetext{
${ }^{20}$ Ali Hasaballah, Qiyâs al-Maslahah.(Mesir: Dâr alMaârif, 1383 H/1964 M), p.257

${ }^{21}$ Yusuf al-Qaradawi, Madkhal li Dirâsat al-Syarî́ah
} 
According to al-Gazâli's view, based on the aspect of whether or not there is Syarass firm justification for him (syahâdat asy-syar'i), maslahah is divided into three, namely (1) maslahah which has confirmed Syarass justification for its acceptance (maslahah mustabarah); (2) maslahah which was confirmed by Syara' justification for his refusal (maslahah mulgâh); and (3) maslahah which is not confirmed by Syara' justification, both for its acceptance and rejection (maslahah mursalah). Muhammad Muslehuddin saw that the maslahah categorization with the trilogy maslahah murtabarah, maslahah mulgâh, and maslahah mursalah still had to consider the dimensions of society's interests and the changing social reality so that Islamic law (Sharia) must move in line with changes in social reality that occur, in turn, the flexibility of Islamic law (Sharia) can be maintained. ${ }^{22}$

On the other hand, al-Gazâli also categorizes maslahah based on the strength of its substance (quwwatihâ fî dzâtiha), where maslahah is divided into three, namely (1) maslahah darûrât level, (2) maslahah level hâjât level, and (3) maslahah level tahsîniyât/tazyînat. Each part is accompanied by a complementary maslahah/complement (takmilah/tatimmah). The maintenance of the five basic goals/ principles (al-usûl al-khamsah), which is at the emergency level is the strongest and highest level of maslahah. The five basic objectives/ principles include (1) maintaining religion (hifz ad-dîn), (2) maintaining the soul (hifz annafs), (3) maintaining intellect (hifz al-'aql), (4) maintaining offspring ( hifz an-nasl), and (5) maintaining wealth (hifz al-mâl). Al-Gazaliss

al-Islâmiyyah, (Kairo: Maktabah Wahbah,1990), p. 62.

${ }^{22}$ Yusuf al-Qaradawi, Madkhal li Dirâsat..., p. 65. view of al-usûl al-khamsah was refined by Syihâb al-Dîn al-Qarafi by adding one more objective/basic principle, namely maintaining self-respect (hifzal-sird) even though al-Qarafi himself acknowledged that this is the subject of debate by scholars. ${ }^{23}$

Meanwhile, in the second case, the determination of the compensation, the panel of judges issued a ruling based on the fact that their marriage could be carried out immediately because the applicants were consensual and always together and there was a concern that unwanted things would occur in Religion and the Law, And this is considering, that the children of the Petitioners, at that time were respectively 18 years and 18 years 4 months, so that based on Article 7 paragraph (1) of Law Number 1 the Year 1974, to marry off there must be dispensation. From the court. Actually, there is no age requirement in Islamic law if you want to carry out a marriage, the requirement that must be met to carry out marriage is baligh.

Based on this information, the requirements described in article 7 , paragraph 1 , are only permitted if the male party has reached 19 years, and the woman has reached 16 years. From the two cases, the authors concluded that the reason the judge fulfilled the petitionerss petition was to emphasize the concern of the petitionerss parents.

BAPPENAS reports that in 2018, underage marriages occurred in Indonesia, nearly $35 \%$ of cases out of 2 million couples who married. The high rate of underage marriage is inseparable from the legal, social and cultural factors that develop in society, concerning:

\footnotetext{
${ }^{23}$ Yusuf al-Qaradawi, Madkhal li Dirâsat..., p. 72.
} 
1. Religious norms (especially Islam) do not prohibit or oppose underage marriage, and there is no criminalization against underage marriage;

2. Habits and traditions that have been entrenched in society;

3. Marriage or marriage as a way to get out of the shackles;

4. The economic downturn and the burden of life;

5. And the tendency to develop promiscuity of adolescents and children. ${ }^{24}$

Meanwhile, if it is observed in the determination of the Marriage Dispensation in the two stipulations, that the reason for applying for an underage marriage is due to the parents/Petitioner's concern about their children's relationship so that the marriage is considered urgent to be implemented.

The existence of maslahah can be seen from the post-determination of the Marriage Dispensation. And from the two determinations that the author examined, one of them did not live together because he was always fighting in his household. And one other, although they still live together, their household life is classified as inadequate due to economic shortages. This proves that the existence of maslahah also needs to pay attention to the emotional and psychological maturity of the prospective brides and the readiness of parents to be responsible for their children $>$ lives after marriage. ${ }^{25}$

For this reason, the authors observe that in determining the Marriage Dispensation,

\footnotetext{
${ }^{24}$ http://bashanovathink.blogspot.com/2011/03/kajiansosiologi-hukum-terhadap.html, on 12 Nopember 2019

25 Results of observations and direct interviews with the person concerned, on December 23, 2019.
}

it is necessary to have a regulation that strengthens the boundaries of matters related to the application for Marriage Dispensation, both in terms of age, psychological impact and economic impact which can be proven in terms of the applicantss ability, in this case, the parents as the person in charge in taking responsibility for the household life of their children after marriage, so that the existence of maslhahah can be realized in real terms.

Furthermore, in Law No.1 of 1974, the reasons for the dispensation of marriage permit should be stated so that the judge in determining the marriage dispensation permit can give the best decision. Judges should also tighten the requirements in applying for a license for dispensation of underage marriage, to reduce the number of cases of early marriage that are currently rife in Indonesia.

\section{Conclusion}

In Indonesia, there are still many parents who marry off their children when they are still underage. This is triggered by various reasons; for example, the culture of marrying young in certain societies. For the poor, marrying off their children is a burden relieving. Apart from the background above factors, another important cause of underage marriage is the rampant promiscuity of adolescents which has resulted in pregnancy outside of marriage. This is also exacerbated by the existence of a marriage dispensation rule, and marriage is only permitted if the man and woman have reached the age of 19 (nineteen) years. In compelling circumstances, marriage below the minimum age limit as stipulated in the Marriage Law is possible after obtaining dispensation from the court at the request of 
the parents. However, the facts in the field are often reversed. This can be seen in the case at the Religious Court Class I B Tanggamus in the case of the determination of Marriage Dispensation Number 008/Pdt.P/2018/ PA. Tgm and 0012/Pdt.P/2019/PA.Tgm is at the request of parents and without any other syariah reason. Judges' considerations in determining the dispensation of marriage Number 0008/Pdt.P/2018/PA.Tgm and 0012/Pdt.P/2019/PA.Tgm turned out to not bring good and benefit to their household. Lack of knowledge, experience, and financial capacity are the cause of domestic conflict.

\section{References}

Abdul, Rahman dan Beni Ahmad. Perkawinan dan Perceraian Keluarga Muslim, cet. ke-1, Bandung: CV Pustaka Setia, 2016.

Ahyani, Sri. "Pertimbangan Pengadilan Agama Atas Dispensasi Pernikahan Usia Dini Akibat Kehamilan Di Luar Nikah", Jurnal Wawasan Hukum, Vol. 34, No. 1, Februari 2016.

Arto, Mukti. Hukum Perkawinan Indonesia Menurut Perundangan, Hukum Adat dan Hukum Agama. Bandung: Mandar Maju, 2017.

Asmawi, "Konseptualisasi Teori Mashlahah", Salam: Jurnal Filsafat dan Budaya Hukum, Vol. 2, No. 1, 2014.

Bisri,Cik Hasan. Model Penelitian Fiqh, Bogor: Kencana, 2013, Cet. ke-1, Jilid I

Daradjat, Zakiyah dalam Ghifari. Bandung: Remaja Rosda Karya, 2016.

Departemen Agama RI, Persetujuan, Izin dan Dispensasi, Depag: Jakarta, 2008.

Hasaballah, 'Ali. Qiyâs al-Maslahah, Mesir: Dâr al-Maârif, 1383 H/1964 M
Hisân, Husain Hamid. Nazariyyatal-Maslahah fi al-Figh al-Islâmiy, Beirut: Dâr alNahdah al-'Arabiyyah, 1971.

Inayah, Nurul. Penetapan Dispensasi Nikah Akibat Hamil Di Luar Nikah Di Pengadilan Agama Yogyakarta Tahun 2010-2015 (Analisis Hukum Acara Peradilan Agama), Jurnal Al-Ahwal, Vol. 10, No. 2, Desember $2017 \mathrm{M} / 1439 \mathrm{H}$.

Latif, Sutan Marajo Nasaruddin Latif. Problematika Seputar Keluarga dan Rumah Tangga, Bandung: Pustaka Hiddayah, 2011.

MK, Anshary, Kamal Muchtar. Asas-Asas Hukum Islam Tentang Perkawinan, Jakarta: Bulan Bintang, 2010.

Munawir, A. Warson. Kamus Al Munawir, Surabaya: Pustaka Progresif, 2016

Prodjohamidjojo, Muhammad, Husen dkk.. Fiqih Seksualitas: Risalah Islam Untuk Pemenuhan Hak-hak Seksual, Yogyakarta: PKBI, 2016

Qaradawi, al-, Yusuf. Madkhal li Dirâsat alSyarî́ah al-Islamiyyah, Kairo: Maktabah Wahbah, 1990

Rofiq, Ahmad, Hilman Hadikusuman. Hukum Perkawinan Indonesia Menurut Perundangan, Hukum Adat dan Hukum Agama, Bandung: Mandar Maju, 2001.

Rukmana, Siti Hardiyanti. "Pertimbangan Non Yuridis Dalam Memutuskan Perkara Dispensasi Nikah (Studi Putusan Pengadilan Agama Tanjung Karang Kelas Ia Kota Bandar Lampung)", Tesis Magister, UIN Raden Intan Lampung 2019, http://repository.radenintan.ac.id/ $\mathrm{id} /$ eprint/6557

Saleh, Fiqh Munakahat, Jakarta: Prenada Media, 2016. 
Sarwono, Sarlito Wirawan dalam Ghifari, Syafei, Rachmat. Ilmu Ushul Fiqih, Bandung: Rahman, Kholil. Hukum Perkawinan Pustaka Setia, 2017.

Islam, Semarang: IAIN Walisongo, 2016.

Syarifudin, Amir. Ushul Fiqih,Jilid 2, Jakarta: Kencana, 2015.

Setiasih, Widihartati. "Analisis Putusan

Thaib, Siskawati. Perkawinan Di bawah Perspektif Perlindungan Perempuan”, Jurnal PPKM III, Vol. 4, No 3, September 2017.

Umur (Ditinjau Dari Hukum Islam Dan Undang-Undang Nomor 1 Tahun 1974), Lex Privatum Vol. V/No. 9/Nov/2017. 